\title{
Article \\ Colistin Resistance and ESBL Production in Salmonella and Escherichia coli from Pigs and Pork in the Thailand, Cambodia, Lao PDR, and Myanmar Border Area
}

\author{
Khin Khin Lay ${ }^{1}$, Saharuetai Jeamsripong ${ }^{2}{ }^{(D}$, Kyaw Phyoe Sunn ${ }^{2,3}$, Sunpetch Angkititrakul ${ }^{4}$ (D), Ransiya Prathan ${ }^{2}$, \\ Songsak Srisanga ${ }^{2}$ and Rungtip Chuanchuen ${ }^{2, *}$ \\ 1 Department of Animal Science, University of Veterinary Science, Nay Phi Tau 15013, Myanmar; \\ khinkhinvph@gmail.com \\ 2 Research Unit in Microbial Food Safety and Antimicrobial Resistance, Department of Veterinary Public \\ Health, Faculty of Veterinary Science, Chulalongkorn University, Bangkok 10330, Thailand; \\ saharuetai.j@chula.ac.th (S.J.); drkyawphyosunn@gmail.com (K.P.S.); rangsiya.p@chula.ac.th (R.P.); \\ songsak.s@chula.ac.th (S.S.) \\ 3 Division of Public Health, Department of Livestock Breeding and Veterinary, Ministry of Agriculture, \\ Livestock and Irrigation, Nay Phi Tau 15011, Myanmar \\ 4 Research Group for Prevention Technology in Livestock, Faculty of Veterinary Medicine, \\ Khon Kaen University, Khon Kaen 40002, Thailand; sunpetch@kku.ac.th \\ * Correspondence: chuanchuen.r@gmail.com; Tel.: +662-218-9578
}

\section{check for} updates

Citation: Lay, K.K.; Jeamsripong, S.; Sunn, K.P.; Angkititrakul, S.; Prathan, R.; Srisanga, S.; Chuanchuen, R. Colistin Resistance and ESBL Production in Salmonella and Escherichia coli from Pigs and Pork in the Thailand, Cambodia, Lao PDR, and Myanmar Border Area. Antibiotics 2021, 10, 657. https:// doi.org/10.3390/antibiotics10060657

Academic Editor: Jonathan Frye

Received: 26 April 2021

Accepted: 28 May 2021

Published: 31 May 2021

Publisher's Note: MDPI stays neutral with regard to jurisdictional claims in published maps and institutional affiliations.

Copyright: (c) 2021 by the authors. Licensee MDPI, Basel, Switzerland. This article is an open access article distributed under the terms and conditions of the Creative Commons Attribution (CC BY) license (https:/ / creativecommons.org/licenses/by/ $4.0 /)$.

\begin{abstract}
The study aimed to examine the prevalence and genetic characteristics of ESBL-production and colistin resistance in Salmonella and Escherichia coli from pigs and pork in the border area among Thailand, Cambodia, Lao PDR, and Myanmar. Salmonella $(n=463)$ and E. coli $(n=767)$ isolates were collected from pig rectal swab from slaughterhouses $(n=441)$ and pork from retail markets ( $n=368)$ during October 2017 and March 2018. All were determined for susceptibility to colistin and cephalosporins, ESBL production and $\mathrm{mcr}$ and ESBL genes. Salmonella was predominantly found in Cambodia (65.8\%). Serovars Rissen (35.6\%) and Anatum (15.3\%) were the most common. The E. coli prevalence in pork was above $91 \%$ in all countries. Colistin-resistance rate in E. coli $(10.4 \%)$ was significantly higher than Salmonella (2.6\%). ESBL-producing Salmonella (1.9\%) and E. coli $(6.3 \%)$ were detected. The $b l a_{\mathrm{CTX}-\mathrm{M}-55}$ and $b l a_{\mathrm{CTX}-\mathrm{M}-14}$ were identified. The $m c r-1$ gene was detected in Salmonella $(n=12)$ and E. coli $(n=68)$. The $m c r-1 /$ bla $a_{\mathrm{CTX}-\mathrm{M}-55}$ and $m c r-3 /$ bla $_{\mathrm{CTX}-\mathrm{M}-55}$ co-concurrence was observed in one Salmonella and three E. coli isolates, respectively. In conclusion, pigs and pork serve as carriers of colistin and new generation cephalosporins resistance. Testing for resistance to last line antibiotics should be included in national AMR surveillance program using One Health approach.
\end{abstract}

Keywords: Escherichia coli; colistin resistance; extended-spectrum $\beta$-lactamase; Salmonella; southeast Asia

\section{Introduction}

Multidrug resistance (MDR) in bacterial pathogens has escalated and become a significant cause of morbidity and mortality worldwide [1]. Resistance to last resort antibiotics (e.g., colistin and newer generation cephalosporins) is of particular concern because it may limit antibiotic therapy for bacterial infections in the near future [2,3].

Cephalosporins (3rd, 4th, and 5th generations) are used for disease treatment in humans and animals [4] and categorized as critically important antimicrobials in both human [5] and veterinary medicine [6]. Over recent years, resistance to cephalosporins have been increasingly reported in humans and animals $[7,8]$ and role of livestock as important sources of extended-spectrum $\beta$-lactamase (ESBL) producers potentially spread to humans through the food chain was highlighted [9]. Resistance to cephalosporins is 
mainly due to the production of ESBLs that confer resistance to most $\beta$-lactams, including new generation cephalosporins and monobactams (e.g., aztreonam), but not cephamycin (e.g., cefoxitin) and carbapenems (e.g., imipenem) [10]. ESBL-encoding genes are primarily located on plasmid that can be horizontally transferred to inter and intra bacterial species. The genes frequently co-exist with other resistance genes on the same large plasmids, resulting in MDR phenotype of ESBL producers $[9,11]$. Colistin or polymyxin E has a narrow antibacterial spectrum mainly against Gram-negative bacteria [12]. Colistin is widely used in pig production for treatment and control of Enterobacteriaceae infections. Colistin-resistant E. coli carrying plasmid-borne $m c r-1$ were isolated from food animals in China in 2016 [13]. Since then, several $m c r$ variants have been identified in livestock in many parts of the world, including countries with zero to marginal use of colistin (e.g., the United States) [14]. The mor variants can occur due to transference of multiple mobile genetic elements. The co-occurrence of variants of $\mathrm{mcr}$ genes and other antimicrobial resistance (AMR) genes can increase the widespread of colistin resistance and pose a global public health risk [15].The border-crossing areas between Thailand and its land neighboring countries including Cambodia, Lao PDR and Myanmar has flourished and become a major route for cross-border trade and tourism owing to their geographical advantages situated along the Mekong river [16]. Purchasing and selling live animals and retail meat, especially pigs and pig products, is one of the high-trade volume and value. The cross-border trade has been emphasized on improvement of their commerce, investment, and economic cooperation [16]. This raises a particular concern over the role of food animals and products as reservoirs of diseases and AMR bacteria that possibly spread to other regions and countries.

Currently, knowledge on resistance to new generation cephalosporins and colistin in bacteria from livestock and products remains largely undiscovered in most cross-border regions globally. This study aimed to examine the prevalence and genetic characteristics of ESBL-production and colistin resistance in Salmonella and E. coli isolated from pigs and pork in the border area between Thailand, Cambodia, Lao PDR, and Myanmar.

\section{Results}

\subsection{Salmonella Prevalence and Serovars in Pigs and Pork}

Half of the samples were positive to Salmonella (49.8\%) (Table 1). The highest Salmonella prevalence was found in Cambodia (65.8\%, 98/149), followed by Thailand $(56.3 \%, 214 / 380)$. The Salmonella positive samples in retail markets $(61.0 \%, 246 / 403)$ was 1.6 times greater than those in slaughterhouses $(39.0 \%, 157 / 403)$. A total of 463 Salmonella isolates with 60 serovars were obtained from Thailand $(n=237)$, Cambodia $(n=121)$, Lao PDR $(n=86)$ and Myanmar $(n=19)$ (Table 2). The most common Salmonella serovars were Rissen (35.6\%), followed by Anatum (15.3\%).

\subsection{E. coli Prevalence in Pork}

The overall percentage of E. coli in pork from the markets was 44.7\% (343/767). The high prevalence $(>88 \%)$ was observed in pork in all countries. The high recovery rate (>94\%) for commensal E. coli was observed for rectal swab sample, indicating the high competence of $E$. coli isolation method used (Table 1). Subtotal of E. coli was not identified in Table 1 to avoid the comparison among the sampling sources since commensal E. coli regularly present in rectal swab. Seven hundred and sixty-seven isolates were collected from Thailand $(n=368)$, Cambodia $(n=136)$, Laos $(n=133)$, and Myanmar $(n=130)$ for further experiments (Table 1 ). 
Table 1. Number of samples and prevalence of Salmonella and E. coli in the border provinces among Thailand, Cambodia, Lao PDR, and Myanmar $(n=809)$.

\begin{tabular}{|c|c|c|c|c|c|c|}
\hline \multirow{2}{*}{ Country } & \multirow{2}{*}{ Location } & \multirow{2}{*}{ Source } & \multirow{2}{*}{ Type of Sample } & \multirow{2}{*}{ No. of Sample } & \multicolumn{2}{|c|}{ No. of Positive Sample (\%) } \\
\hline & & & & & Salmonella & E. coli $^{1}$ \\
\hline \multirow{9}{*}{ Thailand } & \multirow{3}{*}{ Nong Khai } & Slaughterhouse & Rectal swab & 80 & $57(71.3)$ & $79(98.8)$ \\
\hline & & Market & Carcass swab & 60 & $46(76.7)$ & $57(95.0)$ \\
\hline & & & Subtotal & 140 & $103(73.6)$ & - \\
\hline & \multirow{3}{*}{ Sa Kaeo } & Slaughterhouse & Rectal swab & 60 & $2(3.3)$ & $58(96.7)$ \\
\hline & & Market & Carcass swab & 60 & $34(56.7)$ & $58(96.7)$ \\
\hline & & & Subtotal & 120 & $36(30.0)$ & - \\
\hline & \multirow{3}{*}{ Chiangrai } & Slaughterhouse & Rectal swab & 60 & $30(50.0)$ & $58(96.7)$ \\
\hline & & Market & Carcass swab & 60 & $45(75.0)$ & $58(96.7)$ \\
\hline & & & Subtotal & 120 & $75(62.5)$ & - \\
\hline \multirow{3}{*}{ Cambodia } & \multirow{3}{*}{ Banteay Meanchey } & Slaughterhouse & Rectal swab & 84 & $39(46.4)$ & $79(94.0)$ \\
\hline & & Market & Carcass swab & 65 & $59(90.8)$ & $57(87.7)$ \\
\hline & & & Subtotal & 149 & $98(65.8)$ & - \\
\hline \multirow{3}{*}{ Lao PDR } & \multirow{3}{*}{ Vientiane } & Slaughterhouse & Rectal swab & 82 & $28(34.1)$ & $79(96.3)$ \\
\hline & & Market & Carcass swab & 58 & $44(75.9)$ & $54(93.1)$ \\
\hline & & & Subtotal & 140 & $72(51.4)$ & - \\
\hline \multirow{4}{*}{ Myanmar } & \multirow{4}{*}{ Tarchileik } & Slaughterhouse & Rectal swab & 75 & $1(1.3)$ & $71(94.7)$ \\
\hline & & Market & Carcass swab & 65 & $18(27.7)$ & $59(90.8)$ \\
\hline & & & Subtotal & 140 & $19(13.6)$ & - \\
\hline & & & Grand total & 809 & 403 (49.8) & $343(93)^{2}$ \\
\hline
\end{tabular}

${ }^{1}$ subtotal and total percentage was not calculated as commensal E. coli are normally identified in rectal swab. ${ }^{2}$ calculated for carcass swab in markets only.

Table 2. Salmonella serovars from pig and pork samples $(n=468)$ in Thailand, Lao PDR, Cambodia, and Myanmar.

\begin{tabular}{|c|c|c|c|c|c|c|c|c|}
\hline \multirow{3}{*}{$\begin{array}{c}\text { Salmonella } \\
\text { Serotype }\end{array}$} & \multicolumn{8}{|c|}{ No. of Isolates (\%) } \\
\hline & \multicolumn{2}{|c|}{ Thailand $(n=237)$} & \multicolumn{2}{|c|}{ Laos PDR $(n=86)$} & \multicolumn{2}{|c|}{ Cambodia $(n=121)$} & \multicolumn{2}{|c|}{ Myanmar $(n=19)$} \\
\hline & Pig & Pork & Pig & Pork & Pig & Pork & Pig & Pork \\
\hline Typhimurium & $12(5.0)$ & - & $1(1.2)$ & - & $2(1.7)$ & - & - & - \\
\hline Sao & $12(5.0)$ & $8(3.3)$ & - & - & - & - & - & - \\
\hline Augustenborg & $1(0.4)$ & $1(0.4)$ & - & $2(2.3)$ & - & - & - & - \\
\hline Schwarzengrund & $2(0.8)$ & - & - & $1(1.2)$ & - & - & - & - \\
\hline Derby & $2(0.8)$ & - & - & - & $3(2.5)$ & $1(0.8)$ & - & - \\
\hline Rissen & $37(15.5)$ & $66(27.6)$ & - & $11(12.8)$ & $18(14.9)$ & $30(24.8)$ & $1(5.3)$ & $2(10.5)$ \\
\hline Saintpaul & $2(0.8)$ & $8(3.3)$ & - & $1(1.2)$ & - & - & - & $2(10.5)$ \\
\hline Eastbourne & $1(0.4)$ & - & - & - & - & - & - & - \\
\hline Anatum & $8(3.3)$ & 30 (12.6) & $5(5.8)$ & $5(5.8)$ & - & $9(7.4)$ & - & $14(73.7)$ \\
\hline Rideau & $1(0.4)$ & $4(1.7)$ & - & $1(1.2)$ & - & - & - & - \\
\hline Sanktmarx & $5(2.1)$ & $10(4.2)$ & $1(1.2)$ & $2(2.3)$ & - & - & - & - \\
\hline Weltevreden & $4(1.7)$ & $1(0.4)$ & - & - & $1(0.8)$ & $1(0.8)$ & - & - \\
\hline Braenderup & $1(0.4)$ & - & - & - & - & $2(1.7)$ & - & - \\
\hline Fareham & $4(1.7)$ & $2(0.8)$ & - & - & - & - & - & - \\
\hline Stanley & $2(0.8)$ & $1(0.4)$ & $8(9.3)$ & $7(8.1)$ & $3(2.5)$ & $5(4.1)$ & - & - \\
\hline Vijle-1 & - & $1(0.4)$ & - & - & - & - & - & - \\
\hline Norwich & - & $2(0.8)$ & - & $1(1.2)$ & - & - & - & - \\
\hline Yalding & - & $4(1.7)$ & - & - & - & - & - & - \\
\hline Calabar & - & $1(0.4)$ & - & - & - & - & - & - \\
\hline Hayindogo & - & $3(1.3)$ & - & $6(7.0)$ & - & $1(0.8)$ & - & - \\
\hline Muenster & - & $1(0.4)$ & - & $3(3.5)$ & $1(0.8)$ & $5(4.1)$ & - & - \\
\hline Potto & - & - & $3(3.5)$ & - & - & - & - & - \\
\hline Tsevie & - & - & $1(1.2)$ & - & $2(1.7)$ & - & - & - \\
\hline Brunei & - & - & $4(4.7)$ & - & - & - & - & - \\
\hline
\end{tabular}


Table 2. Cont.

\begin{tabular}{|c|c|c|c|c|c|c|c|c|}
\hline \multirow{3}{*}{$\begin{array}{c}\text { Salmonella } \\
\text { Serotype }\end{array}$} & \multicolumn{8}{|c|}{ No. of Isolates (\%) } \\
\hline & \multicolumn{2}{|c|}{ Thailand $(n=237)$} & \multicolumn{2}{|c|}{ Laos PDR $(n=86)$} & \multicolumn{2}{|c|}{ Cambodia $(n=121)$} & \multicolumn{2}{|c|}{ Myanmar $(n=19)$} \\
\hline & Pig & Pork & Pig & Pork & Pig & Pork & Pig & Pork \\
\hline Kissi & - & - & $1(1.2)$ & - & - & - & - & - \\
\hline Eschberg & - & - & $1(1.2)$ & - & - & - & - & - \\
\hline Ayinde & - & - & $1(1.2)$ & - & - & - & - & - \\
\hline Kentucky & - & - & $1(1.2)$ & $2(2.3)$ & - & - & - & - \\
\hline Rottnest & - & - & $1(1.2)$ & - & - & - & - & - \\
\hline Vilvoorde & - & - & $1(1.2)$ & - & - & - & - & - \\
\hline Kouka & - & - & $1(1.2)$ & - & - & - & - & - \\
\hline Portanigra & - & - & - & $1(1.2)$ & - & - & - & - \\
\hline Newlands & - & - & - & $2(2.3)$ & - & - & - & - \\
\hline Bristol & - & - & - & $1(1.2)$ & - & - & - & - \\
\hline Sandow & - & - & - & $1(1.2)$ & - & $10(8.3)$ & - & - \\
\hline Haifa & - & - & - & $1(1.2)$ & - & $1(0.8)$ & - & - \\
\hline Magumeri & - & - & - & $1(1.2)$ & - & - & - & - \\
\hline Lika & - & - & - & $1(1.2)$ & - & - & - & - \\
\hline $\mathrm{V}$ & - & - & - & $1(1.2)$ & - & - & - & - \\
\hline Koenigstuhl & - & - & - & $1(1.2)$ & $1(0.8)$ & - & - & - \\
\hline II & - & - & - & $1(1.2)$ & - & $1(0.8)$ & - & - \\
\hline Suberu & - & - & - & $1(1.2)$ & - & - & - & - \\
\hline Ikayi & - & - & - & $2(2.3)$ & - & - & - & - \\
\hline Dallgow & - & - & - & - & $1(0.8)$ & - & - & - \\
\hline Paratyphi-B & - & - & - & - & $1(0.8)$ & - & - & - \\
\hline Lekke & - & - & - & - & $1(0.8)$ & - & - & - \\
\hline Herston & - & - & - & - & $1(0.8)$ & - & - & - \\
\hline Hvittingfoss/II & - & - & - & - & $1(0.8)$ & - & - & - \\
\hline Stanley ville & - & - & - & - & $1(0.8)$ & - & - & - \\
\hline Bradford & - & - & - & - & $1(0.8)$ & - & - & - \\
\hline Yoruba & - & - & - & - & $1(0.8)$ & - & - & - \\
\hline Rechovot & - & - & - & - & $4(3.3)$ & - & - & - \\
\hline Bracknell & - & - & - & - & $1(0.8)$ & - & - & - \\
\hline Idikan & - & - & - & - & $1(0.8)$ & - & - & - \\
\hline Sinstorf & - & - & - & - & - & $5(4.1)$ & - & - \\
\hline Paris & - & - & - & - & - & $1(0.8)$ & - & - \\
\hline Newport & - & - & - & - & - & $1(0.8)$ & - & - \\
\hline Ituri & - & - & - & - & - & $1(0.8)$ & - & - \\
\hline Kedougou & - & - & - & - & - & $1(0.8)$ & - & - \\
\hline Havana & - & - & - & - & - & $1(0.8)$ & - & - \\
\hline Total & $94(39.7)$ & $143(60.3)$ & $30(34.9)$ & $56(65.1)$ & 45 (37.2) & $76(62.8)$ & $1(5.3)$ & $18(94.7)$ \\
\hline
\end{tabular}

\subsection{ESBL Production and Colistin Resistance in Salmonella and E. coli}

Of all Salmonella, colistin-resistant Salmonella was found at low frequency (2.8\%) (Table 3). Colistin-resistant Salmonella were found in pork from Myanmar (5.6\%), Cambodia $(5.3 \%)$, Thailand $(4.2 \%)$, and Laos $(1.8 \%)$. Cephalsosporin-resistance rates were still low $(<2.4 \%)$, of which the Thai pork isolates exhibited the highest prevalence to all cephalosporins tested (Table 4 ).

For E. coli, overall colistin-resistance rate (10.4\%) was significantly higher $(p<0.05)$ than that in Salmonella (Tables 3 and 4). Colistin resistance was most common in Lao PDR $(28.6 \%, 38 / 133)$, where the highest rate was observed among the pork isolates $(37.0 \%$, $20 / 54)$. Resistance rates to ceftazidime $(6.4 \%)$ cefotaxime $(9.0 \%)$ and cefpodoxime $(8.7 \%)$ in E. coli were higher than those in Salmonella (Table 4). 
Table 3. Distribution of phenotypic and genotypic of ESBL production and colistin resistance in Salmonella $(n=463)$ and E. coli $(n=767)$.

\begin{tabular}{|c|c|c|c|c|c|c|c|c|c|c|c|c|c|c|c|c|c|}
\hline \multirow{3}{*}{ Country } & \multirow{3}{*}{ Source } & \multirow{3}{*}{ Total No. } & \multicolumn{6}{|c|}{ Salmonella } & \multirow{3}{*}{ Source } & \multirow{3}{*}{ Total No. } & \multicolumn{7}{|c|}{ E. coli } \\
\hline & & & \multicolumn{3}{|c|}{ ESBL Production, No. $(\%)^{1}$} & \multicolumn{3}{|c|}{ Colistin Resistance, No. $(\%)^{2}$} & & & \multicolumn{4}{|c|}{ ESBL Production, No. $(\%)^{1}$} & \multicolumn{3}{|c|}{ Colistin Resistance, No. $(\%)^{2}$} \\
\hline & & & Total & $b l a_{\text {CTX-M-55 }}$ & $b l a_{\text {TEM-1 }}$ & Total & $m c r-1$ & $m c r-3$ & & & Total & bla $a_{\mathrm{CTX}-\mathrm{M}-5}$ & $b l a_{\mathrm{CTX}-\mathrm{M}-14}$ & $b l a_{\text {TEM-1 }}$ & Total & $m c r-1$ & $m c r-3$ \\
\hline Thailand & $\begin{array}{l}\text { Pig } \\
\text { Pork } \\
\text { Total }\end{array}$ & $\begin{array}{c}94 \\
143 \\
237\end{array}$ & $\begin{array}{l}2(2.1) \\
6(4.2) \\
8(3.4)\end{array}$ & $\begin{array}{l}1(1.1) \\
6(4.2) \\
7(3.0)\end{array}$ & $\begin{array}{l}1(1.1) \\
6(4.2) \\
7(3.0)\end{array}$ & $\begin{array}{c}- \\
6(4.2) \\
6(2.5)\end{array}$ & $\begin{array}{c}- \\
6(4.2) \\
6(2.5)\end{array}$ & $\begin{array}{c}1(1.1) \\
- \\
1(0.4)\end{array}$ & $\begin{array}{l}\text { Pig } \\
\text { Pork } \\
\text { Total }\end{array}$ & $\begin{array}{l}195 \\
173 \\
368\end{array}$ & $\begin{array}{c}12(6.2) \\
9(5.2) \\
21(5.7)\end{array}$ & $\begin{array}{c}8(4.1) \\
6(3.5) \\
14(3.8)\end{array}$ & $\begin{array}{l}4(2.1) \\
4(2.3) \\
8(2.2)\end{array}$ & $\begin{array}{c}7(3.6) \\
6(3.5) \\
13(3.5)\end{array}$ & $\begin{array}{c}8(4.1) \\
14(8.1) \\
22(6.0)\end{array}$ & $\begin{array}{c}11(5.6) \\
6(3.5) \\
17(4.6)\end{array}$ & $\begin{array}{l}5(2.6) \\
4(2.3) \\
9(2.4)\end{array}$ \\
\hline Cambodia & $\begin{array}{l}\text { Pig } \\
\text { Pork } \\
\text { Total } \\
\end{array}$ & $\begin{array}{c}45 \\
76 \\
121 \\
\end{array}$ & $\begin{array}{l}- \\
- \\
-\end{array}$ & $\begin{array}{l}- \\
- \\
-\end{array}$ & $\begin{array}{l}- \\
- \\
-\end{array}$ & $\begin{array}{c}- \\
4(5.3) \\
4(3.3)\end{array}$ & $\begin{array}{c}- \\
4(5.3) \\
4(3.3)\end{array}$ & - & $\begin{array}{l}\text { Pig } \\
\text { Pork } \\
\text { Total }\end{array}$ & $\begin{array}{c}79 \\
57 \\
136 \\
\end{array}$ & $\begin{array}{l}2(2.5) \\
1(1.8) \\
3(2.2) \\
\end{array}$ & $\begin{array}{l}2(2.5) \\
1(1.8) \\
3(2.2)\end{array}$ & $\begin{array}{l}- \\
- \\
-\end{array}$ & $\begin{array}{c}2(2.5) \\
- \\
2(1.5) \\
\end{array}$ & $\begin{array}{c}11(13.9) \\
7(12.3) \\
18(13.2)\end{array}$ & $\begin{array}{c}9(11.4) \\
4(7.0) \\
13(9.6) \\
\end{array}$ & $\begin{array}{c}5(6.3) \\
5(8.8) \\
10(7.4)\end{array}$ \\
\hline Lao PDR & $\begin{array}{l}\text { Pig } \\
\text { Pork } \\
\text { Total }\end{array}$ & $\begin{array}{l}30 \\
56 \\
86\end{array}$ & $\begin{array}{l}- \\
1(1.8) \\
1(1.2)\end{array}$ & $\begin{array}{l}-\overline{1} \\
1(1.8) \\
1(1.2)\end{array}$ & $\begin{array}{l}- \\
- \\
-\end{array}$ & $\begin{array}{l}- \\
1(1.8) \\
1(1.2)\end{array}$ & $\begin{array}{l}1- \\
1(1.8) \\
1(1.2)\end{array}$ & $\begin{array}{l}- \\
- \\
-\end{array}$ & $\begin{array}{l}\text { Pig } \\
\text { Pork } \\
\text { Total }\end{array}$ & $\begin{array}{c}79 \\
54 \\
133\end{array}$ & $\begin{array}{c}6(7.6) \\
- \\
6(4.5)\end{array}$ & $\begin{array}{l}2(2.5) \\
1(1.9) \\
3(2.6)\end{array}$ & $\begin{array}{c}4(5.1) \\
- \\
4(3.0)\end{array}$ & $\begin{array}{c}5(6.3) \\
- \\
5(3.8)\end{array}$ & $\begin{array}{l}18(22.8) \\
20(37.0) \\
38(28.6)\end{array}$ & $\begin{array}{l}16(20.3) \\
17(31.5) \\
33(24.8)\end{array}$ & $\begin{array}{l}6(7.6) \\
6(11.1) \\
12(9.0)\end{array}$ \\
\hline Myanmar & $\begin{array}{l}\text { Pig } \\
\text { Pork } \\
\text { Total }\end{array}$ & $\begin{array}{c}1 \\
18 \\
19\end{array}$ & $\begin{array}{l}- \\
- \\
-\end{array}$ & $\begin{array}{l}- \\
- \\
-\end{array}$ & $\begin{array}{l}- \\
- \\
-\end{array}$ & $\begin{array}{l}- \\
1(5.6) \\
1(5.6)\end{array}$ & $\begin{array}{l}- \\
1(5.6) \\
1(5.3)\end{array}$ & $\begin{array}{l}- \\
- \\
-\end{array}$ & $\begin{array}{l}\text { Pig } \\
\text { Pork } \\
\text { Total }\end{array}$ & $\begin{array}{c}71 \\
59 \\
130\end{array}$ & $\begin{array}{c}13(18.3) \\
5(8.5) \\
18(13.8)\end{array}$ & $\begin{array}{c}10(14.1) \\
4(6.8) \\
14(10.8)\end{array}$ & $\begin{array}{l}3(4.2) \\
1(1.7) \\
4(3.1)\end{array}$ & $\begin{array}{l}5(7.0) \\
1(1.7) \\
6(4.6)\end{array}$ & $\begin{array}{c}-\overline{-} \\
2(3.4) \\
2(1.5)\end{array}$ & $\begin{array}{l}2(2.8) \\
3(5.1) \\
5(3.8)\end{array}$ & $\begin{array}{l}- \\
- \\
-\end{array}$ \\
\hline & $\begin{array}{l}\text { Grand } \\
\text { total }\end{array}$ & 463 & $9(1.9)$ & $8(1.7)$ & $7(1.5)$ & $13(2.8)$ & $12(2.6)$ & $1(0.2)$ & $\begin{array}{l}\text { Grand } \\
\text { total }\end{array}$ & 767 & $48(6.3)$ & $34(4.4)$ & $16(2.1)$ & $26(3.4)$ & $80(10.4)$ & $68(8.9)$ & $31(4.0)$ \\
\hline
\end{tabular}

${ }^{1}$ ESBL genes were examined in all ESBL producers. ${ }^{2}$ mor genes were tested in all isolates.

Table 4. Cephalosporin resistant Salmonella $(n=463)$ and E. coli $(n=767)$ from pig and pork.

\begin{tabular}{|c|c|c|c|c|c|c|c|c|c|}
\hline \multirow{3}{*}{ Country } & \multirow{3}{*}{ Source } & \multicolumn{4}{|c|}{ Salmonella } & \multicolumn{4}{|c|}{ E. coli } \\
\hline & & \multirow{2}{*}{ Total No. } & \multicolumn{3}{|c|}{ No. of Positive (\%) } & \multirow{2}{*}{ Total No. } & \multicolumn{3}{|c|}{ No. of Positive (\%) } \\
\hline & & & Ceftazidime & Cefotaxime & Cefpodoxime & & Ceftazidime & Cefotaxime & Cefpodoxime \\
\hline \multirow{3}{*}{ Thailand } & Pigs & 94 & $3(3.2)$ & $2(2.1)$ & $3(3.2)$ & 195 & $12(6.2)$ & $19(9.7)$ & $19(9.7)$ \\
\hline & Pork & 143 & $5(3.5)$ & $6(4.2)$ & $6(4.2)$ & 173 & $14(8.1)$ & 15 (8.7) & $16(9.2)$ \\
\hline & Total & 237 & $8(3.4)$ & $8(3.4)$ & $9(3.8)$ & 368 & $26(7.1)$ & $34(9.2)$ & $35(9.5)$ \\
\hline \multirow{3}{*}{ Cambodia } & Pigs & 45 & $1(2.2)$ & $1(2.2)$ & $1(2.2)$ & 79 & $3(3.8)$ & $4(5.1)$ & $2(2.5)$ \\
\hline & Pork & 76 & - & - & - & 57 & $4(7.0)$ & $1(1.8)$ & $1(1.8)$ \\
\hline & Total & 121 & $1(0.8)$ & $1(0.8)$ & $1(0.8)$ & 136 & $7(5.1)$ & $5(3.7)$ & $3(2.2)$ \\
\hline \multirow[t]{2}{*}{ Lao PDR } & Pork & 56 & $1(1.8)$ & $1(1.8)$ & $1(1.8)$ & 54 & 1 (1.9) & $1(1.9)$ & 1 (1.9) \\
\hline & Total & 86 & $2(2.3)$ & $2(2.3)$ & $2(2.3)$ & 133 & $4(3.0)$ & $9(6.8)$ & $8(6.0)$ \\
\hline \multirow{4}{*}{ Myanmar } & Pigs & 1 & - & - & - & 71 & $7(9.9)$ & 13 (18.3) & $13(18.3)$ \\
\hline & Pork & 18 & $1(5.6)$ & - & - & 59 & $5(8.5)$ & $8(13.6)$ & $8(13.6)$ \\
\hline & Total & 19 & $1(5.6)$ & - & - & 130 & $12(9.2)$ & $21(16.2)$ & $21(16.2)$ \\
\hline & Grand total & 463 & $12(2.6)$ & $11(2.4)$ & $12(2.6)$ & 767 & $49(6.4)$ & $69(9.0)$ & $67(8.7)$ \\
\hline
\end{tabular}




\subsection{Prevalence of ESBL-Producing Salmonella and E. coli}

The ESBL-producing Salmonella percentage was low (1.9\%, 9/463). The isolates were found only in Thailand $(3.4 \%, 8 / 237)$ and Lao PDR $(1.2 \%, 2 / 86)$ (Table 3$)$.

The overall prevalence of ESBL-producing E. coli was 6.5\% (50/767), of which the highest percentage was among the Myanmar isolates (13.9\%, 18/130) (Table 3).

The prevalence of ESBL-producing E. coli (6.5\%) was significantly different from that of Salmonella (1.9\%). The presence of ESBL-producing E. coli was associated with sample type, and significantly higher in pigs $(7.8 \%, 33 / 424)$ than pork $(5.0 \%, 17 / 343)(\mathrm{OR}=2.88$, $p=0.028$ ). A Salmonella isolate (from Laos) and 4 E. coli from Thailand $(n=2)$ and Cambodia $(n=2)$ were ESBL producers that were additonally resistant to colistin.

\subsection{Genotype of Colistin-Resistant and ESBL-Producing Salmonella and E. coli}

In Salmonella, all colistin-resistant isolates $(n=13)$ carried $m c r-1$ (Table 3). A Thai pig isolate additionally harbored $m c r-3$. Only bla CTX-M55 $_{2}(88.9 \%, 8 / 9)$ was observed in ESBL-producing Salmonella (Table 3). The only ESBL-producing Salmonella from pork in Lao PDR carried both $m c r-1$ and $b l a_{\text {CTX-M55. }}$.

In E. coli, $m c r-1(85 \%, 68 / 80)$ and $m c r-3(38.8 \%, 31 / 80)$ were found (Table 3). Five mcr-1-possitive E. coli from three Thai and two Cambodian pig isolates were susceptible to colistin. Six colistin-resistant E. coli from pigs in Thailand $(n=1)$ and Cambodia $(n=1)$ and pork in Camodia $(n=1)$ and Lao PDR $(n=3)$ carried both $m c r-1$ and $m c r-3$ (colistin $\mathrm{MIC}=4$ and $8 \mu \mathrm{g} / \mathrm{mL})$. The $b l a_{\mathrm{CTX}-\mathrm{M}-55}(70.8 \%, 34 / 48)$ and $b l a_{\mathrm{CTX}-\mathrm{M}-9}(32 \%, 16 / 48)$ genes were detected among the ESBL-producing E. coli. Three E. coli from Thai pig $(n=1)$ and Cambodian pig $(n=1)$ and pork $(n=1)$ harbored both $m c r-3$ and bla $a_{\mathrm{CTX}-\mathrm{M} 55}$.

The $\beta$-lactamase gene, bla $a_{\mathrm{TEM}-1}$, was common in ESBL-producing Salmonella $(77.8 \%$, $7 / 9)$ and E. coli $(54.2 \%, 26 / 48)$. The percentage of ESBL production was statistically associated with bla TEM-1 $_{1}(p<0.05)$.

The $b l a_{\text {CTX-M55 }}$ gene in one ESBL-producing Salmonella from Thai pig and seven ESBLproducing E. coli from Cambodia (one from pig and one from pork) and Myanmar (three from pigs and two from pork) was conjugally transferred.

\section{Discussion}

A major finding in this study was the high prevalence of E. coli contamination in pork in retail markets, in agreement with a previous study [17]. Concurrently, the Salmonella contamination rate was approximately 1.9 times lower than that of E. coli. These observations emphasize that legal framework of microbiological quality of raw meat must be effectively implemented for food safety in retail market facilities among border provinces. In general, retail meat is delivered in open buckets and sold in open-air under ambient temperature. Unsold meat is stored overnight in an icebox for re-selling in the following day. These unhygienic practices contribute to the high bacterial contamination observed. Importantly, Salmonella contamination increased at retail markets, suggesting cross-contamination during slaughtering process or transportation or from environment at retail markets. However, the samples were not collected immediately after slaughtering and before transporting to retail markets, therefore, the hypothesis cannot be scrutinized. Together with the high $E$. coli contamination, it indicates that fresh meat at retail markets serve as a major source of foodborne pathogens and highlights the need for the effective-hygienic practice along food production chain.

Thailand has launched law and regulations to contain Salmonella in poultry since 2010 [18]. The law includes the enforcement of sample collection for Salmonella detection in broiler, laying hens and breeders. Such law has not been specifically issued for pig farm. However, the microbiological quality of meat is regulated under the Microbiological Quality Criteria for Food and Food Contact Containers No.3 (2017), indicating that Salmonella must not be present in $25 \mathrm{~g}$ of fresh and frozen raw meat (either pork or chicken meat) intended 
for human consumption [19]. Therefore, good manufacturing practice is required at both farm and slaughtering process levels to produce Salmonella free raw meat.

In this study, the most common Salmonella serovars were Rissen and Anatum, in agreement with a previous study [20]. Salmonella Enteritidis was not observed in this study. This maybe because the major reservoir of Salmonella Enteritidis is not in swine production in agreement of previous study [17]. ESBL-producing Salmonella and E. coli were present at lower rate when compared to previous studies in Thailand, [21,22] and other countries e.g., Denmark [23], Czech [24], Nigeria [25], and Germany [26]. The differences could be associated with many factors (e.g., sampling period, geographical variations and different antimicrobials usage). This study covered the border provinces of Thailand and 3 neighboring countries (i.e., Cambodia, Lao PDR and Myanmar). However, when compared to our previous study conducted in Thailand-Cambodia border province, the prevalence of ESBL-positive Salmonella (2.2\%) in this study was higher than that observed (1.7\%) in the same area [27]. Due to high cost of cephalosporins, use of these antimicrobials in livestock production will increase investment cost and reduce profits. Therefore, cephalosporins may not be commonly used in food-animals in the study areas. In addition, distribution of ESBL producers is not always a direct effect of cephalosporin usage [28] and could be due to coselection of ESBL genes by other antibiotics, e.g., ampicillins, aminoglycosides, tetracyclines that are commonly used in swine production in Thailand [29].

Most ESBL-producing Salmonella (8\%) and E. coli (54\%) carried bla all carried CTX-M group 1 and 9, in agreement with a previous study showing that $b l a_{\text {CTX-M-positive }}$ E. coli isolates usually non ESBL $b l a_{\mathrm{TEM}-1}$ [30]. This was also supported by the statistical significance of association between ESBL production and bla TEM-1 $(p<0.05)$ observed. In addition, not all ESBL producers in this study carried the ESBL genes tested, indicating the existence of other resistance mechanisms and/or ESBL genes that were not included in this study.

A previous study in the same region demonstrated that CTX-M $\beta$-lactamases were common among ESBL-producing isolates in this study [31]. This was in agreement with the current study where $b l a_{\mathrm{CTX}} \mathrm{M}-55$ of CTX-M- 1 and $b l a_{\mathrm{CTX}-\mathrm{M}-14}$ of CTX-M-9 were predominant. Several studies previously reported the common presence of $b l a_{\mathrm{CTX}-\mathrm{M}-1}$ in food animals in Switzerland, Tunisia, the United Kingdom, and Germany $[9,10,32,33]$. The bla ${ }_{\text {CTX-M55 }}$ genes were located on conjugative plasmids, in agreement with our previous studies [27] and supporting its distribution in this area. Horizontal transfer of $b a_{\mathrm{CTX}-\mathrm{M}-55}$ was under selective pressure of ampicillin in conjugation experiment, highlighting the role of the old generation antibiotic that has been widely used for a long time as a selective pressure for the new generation of clinically important antibiotics. In addition, the $b l a_{\mathrm{CTX}-\mathrm{M}-14}$ gene was most frequently found in ESBL-producing E. coli, in agreement with food animals in China [34] and Denmark [23].

In Thailand, the use of medicated feed containing polymyxins, cephalosporins, fluoroquinolones and others is regulated by the law on "Characteristics and conditions of animal feed containing drugs prohibited from producing, importing, selling and using" that was issued in 2018 [35]. The regulation of antimicrobials drugs (including polymyxins $\mathrm{B}$, colistin and other drugs in penicillin and fluroquinolone groups) that must not be mixed in animal feed for prophylactic purposes was later announced [36]. The use of colistin for short-term treatment can be performed in swine production [37]. Colistin-resistant E. coli was found in pigs and pork, reflecting the use of colistin in pig production in the region. Interestingly, colistin-resistant Salmonella was limited to pork. This is rather a result of cross contamination during slaughtering, transportation, and in retail markets.

Most colistin-resistant Salmonella and E. coli harbored either mcr-1 or mcr-3, supporting the significance of $m c r$ genes on spread of colistin resistance worldwide. However, some colistin-resistant isolates lacked both genes, indicating the existence of other colistinresistance mechanisms not characterized in this study. Colistin-resistant Salmonella and E. coli harboring both $m c r-1$ and $m c r-3$ were isolated, in agreement with previous studies [38]. Their colistin MICs were 4 and $8 \mu \mathrm{g} / \mathrm{mL}$ (data not shown) and not different from those 
with $m c r-1$ and $m c r-3$ alone, suggesting the variable effect of $m c r$ genes on colistin-resistance level. The common presence of $m c r-3$ (either alone or with $m c r-1$ ) has warned about the possibility of its global spread as observed for $m c r-1$. None of $m c r-2$ was observed, in agreement with a previous study [39].

The findings of Salmonella with $m c r-1 /$ bla $_{\mathrm{CTX}-\mathrm{M}-55}(n=1)$ and E. coli with $m c r-3 /$ bla $a_{\mathrm{CTX}-\mathrm{M} 55}$ $(n=3)$ are of particular concern. This is consistent with previous studies [40,41]. Despite the low percentage, the co-occurrence generates impact on human and veterinary medicine due to the potential contribution to the spread of bacteria with clinically important antimicrobial resistance, resulting in limited choice for bacterial infection therapy. Resistance genes in these groups are plasmid borne and potentially distribute to bacteria in humans, other animals and environment, so implementation of One Health approach is needed to alleviate the AMR issue.

\section{Materials and Methods}

\subsection{Sampling Location and Sample Collection}

The sampling area are boundary provinces along the border between Thailand and Cambodia (Sa Kaeo and Banteay Meanchey), Thailand and Lao PDR (Nong Khai and Vientiane), and Thailand and Myanmar (Chiang Rai and Tarchileik) (Figure 1). The samples were collected during 2017-2018. All pig samples were obtained from one municipal pig slaughterhouse and one municipal fresh market in each province.

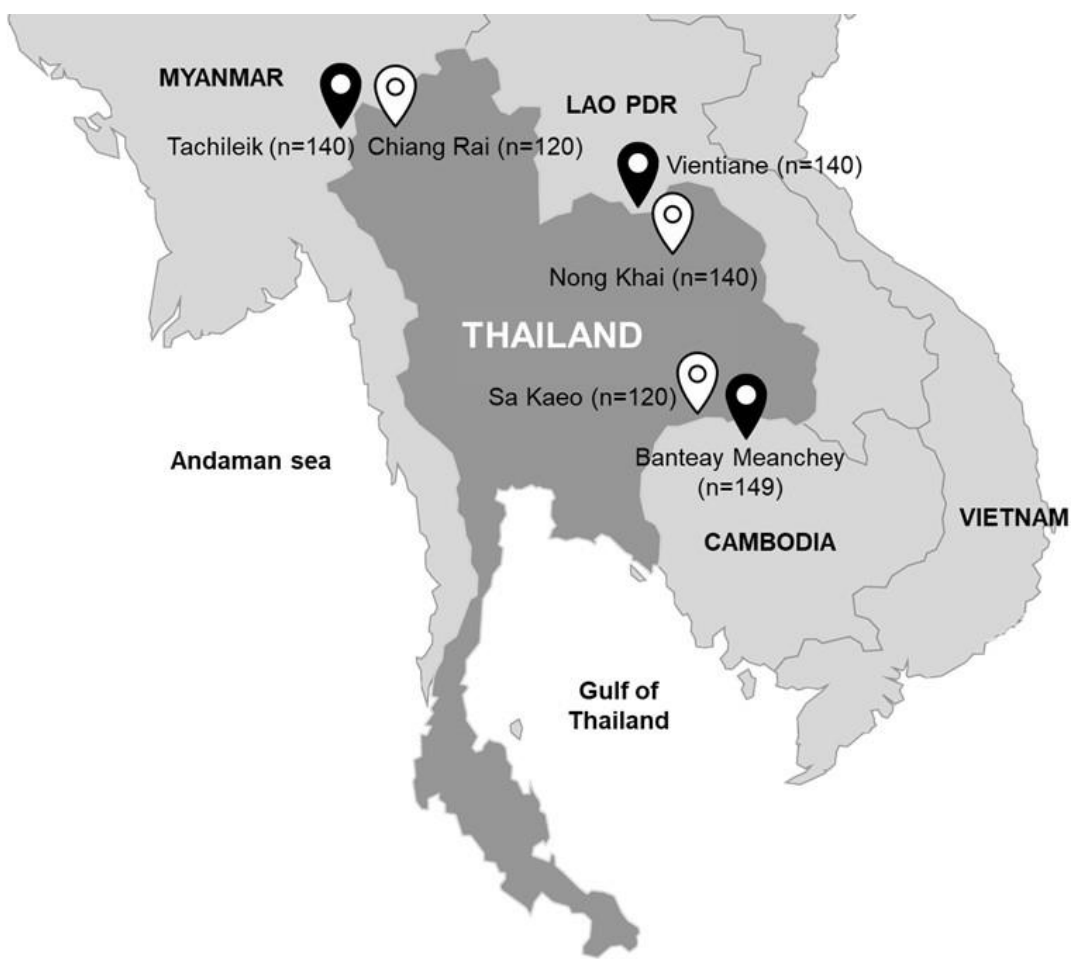

Figure 1. Sampling location in the border provinces between Thailand $(\boldsymbol{9})$ and other neighboring counties $\left({ }^{\circ}\right)$ including Lao PDR, Cambodia and Myanmar. Number of samples is indicated in parenthesis.

All pigs were from commercial production farms that provided meat for domestic consumption. In Thailand, the pig slaughterhouse in Nong Khai was a large-scale facility with greater than 80 pigs were slaughtered each day, while slaughterhouses in Sa Kaeo and Chiang Rai provinces were small-scale modern facilities with no more than 50 pigs were processed daily. The pig slaughterhouses in Banteay Meanchey province, Cambodia and from Tachileik, Myanmar were traditionally small slaughterhouses with a throughput of 30 or fewer pigs per day. In Lao PDR, the pig slaughterhouse in Vientiane was large-scale 
modern facility with a throughput of greater than 200 pigs per day. A total of 809 samples were collected by rectal swab from pigs in slaughterhouses $(n=441)$ and carcass swab in retail markets $(n=368)$ from Thailand $(n=380)$, Cambodia $(n=149)$, Lao PDR $(n=140)$ and Myanmar $(n=140)$ (Table 1$)$.

At slaughterhouses, rectal swab samples were obtained by rectal evacuation after bleeding but prior to scalding. At fresh markets, the pig carcass swab was obtained by swabbing an area of at least $50 \mathrm{~cm}^{2}$ on each fresh carcass. The sample collection was performed three times at each sampling site. All samples were stored in an icebox and transported within $24 \mathrm{~h}$ after collection for immediate processing or held in refrigerator at $4{ }^{\circ} \mathrm{C}$ until exanimation $48 \mathrm{~h}$ of collection.

\subsection{Isolation and Identification of Salmonella and E. coli}

Salmonella was isolated following ISO 6579:2002(E) [42] and subjected to serotyping by slide agglutination based on the Kaufman-White scheme [43]. A single colony of each serotype was collected from each positive sample. E. coli was isolated and biochemically confirmed $[44,45]$. One isolate was collected from each positive sample and all were stored as $20 \%$ glycerol stock at $-80{ }^{\circ} \mathrm{C}$.

\subsection{Determination of Minimum Inhibitory Concentration (MICs) of Colistin}

All the Salmonella $(n=463)$ and E. coli $(n=767)$ isolates were tested for susceptibility to colistin by MIC determination using two-fold agar dilution method [46]. The colistin concentrations ranged from 0.0625 to $64 \mu \mathrm{g} / \mathrm{mL}$. The clinical breakpoint for defining colistin resistance was $2 \mu \mathrm{g} / \mathrm{mL}$ [47]. Multidrug resistance (MDR) was defined as being resistant to at least three different classes of antibiotics.

\subsection{Determination of ESBL Production}

ESBL production was initially screened and confirmed using disk diffusion method in all the Salmonella and E. coli isolates [46]. Initial screening was performed using ceftazidime (30 ug), cefotaxime (30 ug) and cefpodoxime (10 ug) (Oxoid, Hampshire, England). All the isolates resistant to at least one of the indicator cephalosporins were subjected to confirm ESBLs production by using combination disk diffusion method with ceftazidime (30 $\mu \mathrm{g})$ and cefotaxime $(30 \mu \mathrm{g})$ alone and in combination with clavulanic acid $(10 \mu \mathrm{g})$ (Oxoid). A difference of $\geq 5 \mathrm{~mm}$ between the inhibition zone of the cephalosporin/clavulanic acid combination and corresponding cephalosporin disks alone was interpreted as positive ESBL phenotype E. coli ATCC 25922 was used as a quality control strain.

\subsection{PCR and Nucleotide Sequencing}

PCR-template DNA was prepared by whole cell boiled lysate procedure [48]. All the primers used are listed in Table 5. All PCR reactions were performed using GeNei ${ }^{\mathrm{TM}}$ mastermix (Merck, Munich, Germany). PCR amplicons were gel purified using Nucleospin ${ }^{\circledR}$ Gel (Macherey-Nagel, Düren, Germany) and submitted for sequencing using PCR primers at First Base Laboratories (Selangor Darul Ehsan, Malaysia). The obtained DNA sequence was BLAST compared with GenBank database (http:/ / www.ncbi.nlm.nih.gov/ BLAST accessed on 24 May 2021). 
Table 5. Primers used in this study.

\begin{tabular}{|c|c|c|c|c|}
\hline Gene & Primer & Primer Sequence $\left(5^{\prime}-3^{\prime}\right)$ & $\operatorname{Tm}\left({ }^{\circ} \mathrm{C}\right)$ & Reference \\
\hline \multicolumn{5}{|l|}{ MCR } \\
\hline \multirow{2}{*}{$m c r-1$} & CLR-5F & CGGTCAGTCCGTTTGTTC & \multirow{2}{*}{58} & \multirow{2}{*}{ [13] } \\
\hline & CLR-5R & CTTGGTCGGTCTGTA & & \\
\hline \multirow{2}{*}{$m c r-2$} & MCR2-IF & TGTTGCTTGTGCCGATTGGA & \multirow{2}{*}{58} & \multirow{2}{*}{ [39] } \\
\hline & MCR2-IR & AGATGGTATTGTTGGTTGCTG & & \\
\hline \multirow{2}{*}{$m c r-3$} & MCR3-IF & AAATAAAAATTGTTCCGCTTAT & \multirow{2}{*}{58} & \multirow{2}{*}{ [49] } \\
\hline & MCR3-IR & GAATGGAGATCCCCGTTTTT & & \\
\hline \multicolumn{5}{|l|}{ ESBL } \\
\hline \multirow{2}{*}{$b l a_{\mathrm{CTX}-\mathrm{M}}$} & CTX-M up & ATGTGCAGYACCAGTAARGTKATGGC & \multirow{2}{*}{60} & \multirow{2}{*}[50]{} \\
\hline & CTX-M down & TGGGTRAARTARGTSACCAGAAYCAGCGG & & \\
\hline \multirow{2}{*}{$b l a_{\mathrm{TEM}}$} & TEM up & GCGGAACCCCTATTTG & \multirow{2}{*}{50} & \multirow{2}{*}[51]{} \\
\hline & TEM down & TCTAAAGTATATATGAGTAAACTTGGTCTGAC & & \\
\hline \multirow{2}{*}{$b l a_{\mathrm{SHV}}$} & SHV up & TTCGCCTGTGTATTATCTCCCTG & \multirow{2}{*}{50} & \multirow{2}{*}{ [51] } \\
\hline & SHV down & TTAGCGTTGCCAGTGYTCG & & \\
\hline \multirow{2}{*}{$b l a_{\mathrm{CMY}-1}$} & CMY1 up & GTGGTGGATGCCAGCATCC & \multirow{2}{*}{58} & \multirow{2}{*}[51]{} \\
\hline & CMY1 down & GGTCGAGCCGGTCTTGTTGAA & & \\
\hline \multirow{2}{*}{$b l a_{\mathrm{CMY}-2}$} & CMY2 up & GCACTTAGCCACCTATACGGCAG & \multirow{2}{*}{58} & \multirow{2}{*}{ [51] } \\
\hline & CMY2 down & GCTTTTCAAGAATGCGCCAGG & & \\
\hline \multirow{2}{*}{$b l a_{\mathrm{PSE}}$} & PSE up & GCTCGTATAGGTGTTTCCGTTT & \multirow{2}{*}{55} & \multirow{2}{*}[50]{} \\
\hline & PSE down & CGATCCGCCGATGTTCCATCC & & \\
\hline \multirow{2}{*}{$b l a_{\mathrm{CTX}-\mathrm{M} 1}$} & MultiCTXMGp1-F & TTAGGAARTGTGCCGCTGYA & \multirow{2}{*}{688} & \\
\hline & MultiCTXMGp1-R & CGATATCGTTGGTGGTRCCAT & & {$[52]$} \\
\hline & MultiCTXMGp2-F & CGTTAACGGCACGATGAC & & \\
\hline bla & MultiCTXMGp2-R & CGATATCGTTGGTGGTRCCAT & 404 & [52] \\
\hline & MultiCTXMGp8/25-F & AACRCRCAGACGCTCTAC & 326 & [52] \\
\hline bla CТХ-M8/25 & MultiCTXMGp8/25-R & TCGAGCCGGAASGTGTYAT & 326 & [52] \\
\hline & MultiCTXMGp9-F & GTGACAAAGAGAGTGCAACGG & & \\
\hline bla СТХ-М9 & MultiCTXMGp9-R & ATGATTCTCGCCGCTGAAGCC & 850 & [53] \\
\hline hla & CTX-M-15-SF & CACACGTGGAATTTAGGGACT & 996 & [54] \\
\hline${ }^{{ }^{2} l a}$ СТХ-M15 & CTX-M-15-SR & GCCGTCTAAGGCGATAAACA & 990 & {$[34]$} \\
\hline
\end{tabular}

\subsection{Detection of ESBL and mor Genes}

All Salmonella $(n=12)$ and $E$. coli $(n=80)$ resistant to colistin were screened for the presence of $m c r-1$ [13], $m c r-2$ [39], and $m c r-3$ [49]. All the isolates that were confirmed to be ESBL produccers including ESBL-producing Salmonella $(n=9)$ and E. coli $(n=50)$ were examined for $\beta$-lactamase genes including $b l a_{\mathrm{TEM}}, b l a_{\mathrm{SHV}}, b l a_{\mathrm{CMY}-1}$ [51], and bla $a_{\mathrm{CTX}-\mathrm{M}}$ and $b l a_{\mathrm{PSE}-\mathrm{M}}[50]$. CTX-M subgroups including $b l a_{\mathrm{CTX}-\mathrm{M} 1}, b l a_{\mathrm{CTX}-\mathrm{M} 2}, b l a_{\mathrm{CTX}-\mathrm{M} 8 / 25}$ [52], and $b l a_{\mathrm{CTX}-\mathrm{M} 9}$ [53], were further examined in bla $a_{\mathrm{CTX}-\mathrm{M} \text {-positive }} E$. coli. The $E$. coli isolates positive to $b l a_{\mathrm{CTX}-\mathrm{M} 1}$ were examined for bla $a_{\mathrm{CTX}-\mathrm{M} 15}$ [54]. All PCR amplicons were gel purified and submitted for sequencing using PCR primers. The presence of bla $\mathrm{CMY}-2$ was examined [51].

\subsection{Test of Conjugation Transfer of ESBL Genes}

Conjugation experiment was conducted in all ESBL producers using biparental mating method [55]. E. coli MG1655 (rifr MG1655; MIC = $256 \mu \mathrm{g} / \mathrm{mL}$ ) were used as recipient for ESBL-producing Salmonella donors and S. Enteritidis SE12 (rifr SE12; MIC = $256 \mu \mathrm{g} / \mathrm{mL}$ ) was used as recipient for ESBL-producing E. coli donors. All transconjugants selected on LB agar containing rifampicin $(32 \mu \mathrm{g} / \mathrm{mL})$ and ampicillin $(100 \mu \mathrm{g} / \mathrm{mL})$ and were tested for ESBL genes as in correspondent donors.

\subsection{Statistical Analysis}

The significance differences between the prevalence of Salmonella and E. coli and the occurrence of AMR stratified by population, location, and sample type were determined using Pearson's Chi-square or Fisher's exact test. The statistical analyses were performed with IBM SPSS Statistics for Windows, Version 18.0 (SPSS Inc., Chicago, IL, USA). Logistic 
regression analysis was used to measure the strength of association between phenotype and genotype of resistance (STATA SE12, Stata Corp LLC.: College Station, TX, USA). A $p$-value of $<0.05$ was considered statistically significant. Odds ratio and $95 \%$ confidence interval (CI) were calculated.

\section{Conclusions}

Healthy pigs can serve as reservoirs for colistin-resistant and ESBL-producing Salmonella and E. coli that may constitute a public health threat. It highlights the need for surveillance program as well as control and prevention strategic plan for AMR in bacteria of food animal origin at national and regional levels. Standard hygiene and sanitation practices should be enhanced in retail markets to minimize the cross contamination. The epidemiological data will help to understand the root cause of AMR. Guidance of the interventions and evaluation of the success of the inventions from farm to fork is essential for the region.

Author Contributions: Conceptualization, R.C.; methodology, K.K.L., K.P.S., S.A., R.P., and S.S.; software, S.J.; validation, R.C.; formal analysis, S.J.; investigation, R.C.; writing-original draft preparation, S.J.; writing-review and editing, R.C.; visualization, R.C.; supervision, R.C.; project administration, R.P.; funding acquisition, R.C. All authors have read and agreed to the published version of the manuscript.

Funding: This study was supported by National Research University Project, Office of Higher Education Commission [NRU59-015-HR] and partly by Thailand Research Fund (TRF) Basic Research Grant [BRG6080014] and Chulalongkorn University-the One Health Research Cluster. K.K.L was supported by Rachadapisek Sompote Fund for Postdoctoral Fellowship, Chulalongkorn University. KPS is a recipient of the ASEAN scholarship program for ASEAN countries, Chulalongkorn University.

Institutional Review Board Statement: Not applicable.

Informed Consent Statement: Not applicable.

Data Availability Statement: The data presented in this study are available in the article.

Acknowledgments: We would like to thank Department of Livestock Development for their assistance in sample collection.

Conflicts of Interest: The authors declare no conflict of interest.

\section{References}

1. Dadgostar, P. Antimicrobial Resistance: Implications and Costs. Infect. Drug Resist. 2019, 12, 3903-3910. [CrossRef] [PubMed]

2. Palumbi, S.R. Humans as the world's greatest evolutionary force. Science 2001, 293, 1786-1790. [CrossRef]

3. Fair, R.J.; Tor, Y. Antibiotics and bacterial resistance in the 21st century. Perspect. Med. Chem. 2014, 6, 25-64. [CrossRef] [PubMed]

4. Cavaco, L.M.; Abatih, E.; Aarestrup, F.M.; Guardabassi, L. Selection and persistence of CTX-M-producing Escherichia coli in the intestinal flora of pigs treated with amoxicillin, ceftiofur, or cefquinome. Antimicrob. Agents Chemother. 2008, 52, $3612-3616$. [CrossRef] [PubMed]

5. WHO; WHO Advisory Group on Integrated Surveillance of Antimicrobial Resistance (AGISAR). Critically Important Antimicrobials for Human Medicine, 3rd ed.; WHO: Geneva, Switzerland, 2012; Available online: https:/ / www.alimenti-salute.it/sites/default/ files/CIA \T1 \textquoterights\%20human_WHO_2011_eng.pdf (accessed on 24 March 2021).

6. OIE. OIE List of Antimicrobials of Veterinary Importance 2007. Resolution No. XXVIII, General Session.: 1-7. WHO 2007. Available online: https://www.oie.int/fileadmin/Home/eng/Internationa_Standard_Setting/docs/pdf/OIE_list_antimicrobials.pdf (accessed on 24 December 2019).

7. Panta, K.; Ghimire, P.; Rai, S.K.; Mukhiya, R.K.; Singh, R.N.; Rai, G. Antibiogram typing of gram negative isolates in different clinical samples of a tertiary hospital. Asian J. Pharm. Clin. Res. 2013, 6, 153-156.

8. Shaikh, S.; Fatima, J.; Shakil, S.; Rizvi, S.M.D.; Kamal, M.A. Antibiotic resistance and extended spectrum beta-lactamases: Types, epidemiology and treatment. Saudi J. Biol. Sci. 2015, 22, 90-101. [CrossRef]

9. Geser, N.; Stephan, R.; Hächler, H. Occurrence and characteristics of extended-spectrum $\beta$-lactamase (ESBL) producing Enterobacteriaceae in food producing animals, minced meat and raw milk. BMC Vet. Res. 2012, 8, 21. [CrossRef]

10. Ben Sallem, R.; Ben Slama, K.; Sáenz, Y.; Rojo-Bezares, B.; Estepa, V.; Jouini, A.; Gharsa, H.; Klibi, N.; Boudabous, A.; Torres, C. Prevalence and characterization of extended-spectrum beta-lactamase (ESBL)-and CMY-2-producing Escherichia coli isolates from healthy food-producing animals in Tunisia. Foodborne Pathog. Dis. 2012, 9, 1137-1142. [CrossRef]

11. Sihem, M.; Salah, H.; Riadh, M.; Salah, A.M. Overview of ESBL-producing Escherichia coli of Animal Origin in Tunisia: In the Way of the Global Spread of CTX-M $\beta$-Lactamases. Arch. Clin. Microbiol. 2015, 6, 1-7. 
12. Catry, B.; Cavaleri, M.; Baptiste, K.; Grave, K.; Grein, K.; Holm, A.; Jukes, H.; Liebana, E.; Navas, A.L.; Mackay, D.; et al. Use of colistin-containing products within the European Union and European Economic Area (EU/EEA): Development of resistance in animals and possible impact on human and animal health. Int. J. Antimicrob. Agents 2015, 46, 297-306. [CrossRef]

13. Liu, Y.Y.; Wang, Y.; Walsh, T.R.; Yi, L.X.; Zhang, R.; Spencer, J.; Doi, Y.; Tian, G.; Dong, B.; Huang, X.; et al. Emergence of plasmid-mediated colistin resistance mechanism MCR-1 in animals and human beings in China: A microbiological and molecular biological study. Lancet Infect. Dis. 2016, 16, 161-168. [CrossRef]

14. Butaye, P.; Wang, C. Colistin resistance, beyond the current knowledge. EBioMedicine 2018, 34, 16-17. [CrossRef] [PubMed]

15. Long, H.; Feng, Y.; Ma, K.; Liu, L.; McNally, A.; Zong, Z. The co-transfer of plasmid-borne colistin-resistant genes mcr-1 and $m c r-3.5$, the carbapenemase gene bla $a_{\mathrm{NDM}-5}$ and the $16 \mathrm{~S}$ methylase gene rmtB from Escherichia coli. Sci. Rep. 2019, 9, 696. [CrossRef] [PubMed]

16. Manarungsan, S. Thailand's Trade Relations with GMS and CLMV. In Japan and Korea with Mekong River Basin Countries; Kagami, M., Ed.; BRV Research Report No. 3; Bangkok Research Center, IDE-JETRO: Bangkok, Thailand, 2010; Available online: https:/ / www.ide.go.jp/library/English/Publish/Download/Brc/pdf/03_chapter6.pdf (accessed on 24 March 2021).

17. Trongjit, S.; Angkittitrakul, S.; Chuanchuen, R. Occurrence and molecular characteristics of antimicrobial resistance of Escherichia coli from broilers, pigs and meat products in Thailand and Cambodia provinces. Microbiol. Immunol. 2016, 60, 575-585. [CrossRef] [PubMed]

18. DLD. Control Salmonella in Poultry. Notification of the Department of Livestock Development. The Ministry of Agriculture and Cooperatives, Thailand. 2010. Available online: http:/ / www.ratchakitcha.soc.go.th (accessed on 20 May 2021).

19. BQSF. Microbiological Quality Criteria for Food and Food Contact Containers No. 3. Notification of the Bureau of Quality and Safety of Food, Department of Medical Sciences, The Ministry of Public Health, Thailand. 2017. Available online: http: / / bqsf.dmsc.moph.go.th (accessed on 20 May 2021).

20. Pornsukarom, S.; Patchanee, P.; Erdman, M.; Cray, P.F.; Wittum, T.; Lee, J.; Gebreyes, W.A. Comparative phenotypic and genotypic analyses of Salmonella Rissen that originated from food animals in Thailand and United States. Zoonoses Public Health. 2015, 62, 151-158. [CrossRef]

21. Boonyasiri, A.; Tangkoskul, T.; Seenama, C.; Saiyarin, J.; Tiengrim, S.; Thamlikitkul, V. Prevalence of antibiotic resistant bacteria in healthy adults, foods, food animals, and the environment in selected areas in Thailand. Pathog. Glob. Health 2014, 108, 235-245. [CrossRef]

22. Nuangmek, A.; Rojanasthien, S.; Chotinun, S.; Yamsakul, P.; Tadee, P.; Thamlikitkul, V.; Tansakul, N.; Patchanee, P. Antimicrobial Resistance in ESBL-Producing Escherichia coli Isolated from Layer and Pig Farms in Thailand. Acta. Sci. Vet. 2018, 46, 8. Available online: https://seer.ufrgs.br/ActaScientiaeVeterinariae/article/view/81823 (accessed on 15 April 2021). [CrossRef]

23. Hammerum, A.M.; Larsen, J.; Andersen, V.D.; Lester, C.H.; Skytte, T.S.S.; Hansen, F.; Olsen, S.S.; Mordhorst, H.; Skov, R.L.; Aarestrup, F.M.; et al. Characterization of extended-spectrum $\beta$-lactamase (ESBL)-producing Escherichia coli obtained from Danish pigs, pig farmers and their families from farms with high or no consumption of third-or fourth-generation cephalosporins. $J$. Antimicrob. Chemother. 2014, 69, 2650-2657. [CrossRef]

24. Zelendova, M.; Dolejska, M.; Masarikova, M.; Jamborova, I.; Vasek, J.; Smola, J.; Manga, I.; Cizek, A. CTX-M-producing Escherichia coli in pigs from a Czech farm during production cycle. Lett. Appl. Microbiol. 2020, 71, 369-376. [CrossRef]

25. Olowe, O.A.; Adewumi, O.; Odewale, G.; Ojurongbe, O.; Adefioye, O.J. Phenotypic and molecular characterisation of extendedspectrum beta-lactamase producing Escherichia coli obtained from animal fecal samples in Ado Ekiti, Nigeria. J. Environ. Public Health 2015, 2015, 497980. [CrossRef]

26. Schill, F.; Abdulmawjood, A.; Klein, G.; Reich, F. Prevalence and characterization of extended-spectrum $\beta$-lactamase (ESBL) and AmpC $\beta$-lactamase producing Enterobacteriaceae in fresh pork meat at processing level in Germany. Int. J. Food Microbiol. 2017, 257, 58-66. [CrossRef]

27. Trongjit, S.; Angkititrakul, S.; Tuttle, R.E.; Poungseree, J.; Padungtod, P.; Chuanchuen, R. Prevalence and antimicrobial resistance in Salmonella enterica isolated from broiler chickens, pigs and meat products in Thailand-Cambodia border provinces. Microbiol. Immunol. 2017, 61, 23-33. [CrossRef]

28. Guiral, E.; Pons, M.J.; Vubil, D.; Marí-Almirall, M.; Sigaúque, B.; Soto, S.M.; Alonso, P.L.; Ruiz, J.; Vila, J.; Mandomando, I. Epidemiology and molecular characterization of multidrug-resistant Escherichia coli isolates harboring bla $a_{\mathrm{CTX}-\mathrm{M}}$ group 1 extendedspectrum $\beta$-lactamases causing bacteremia and urinary tract infection in Manhiça, Mozambique. Infect. Drug Resist. 2018, 11, 927-936. [CrossRef]

29. Coyne, L.; Arief, R.; Benigno, C.; Giang, V.N.; Huong, L.Q.; Jeamsripong, S.; Kalpravidh, W.; McGrane, J.; Padungtod, P.; Patrick, I.; et al. Characterizing Antimicrobial Use in the Livestock Sector in Three South East Asian Countries (Indonesia, Thailand, and Vietnam). Antibiotics 2019, 8, 33. [CrossRef] [PubMed]

30. Tamang, M.D.; Nam, H.M.; Kim, S.R.; Chae, M.H.; Jang, G.C.; Jung, S.C.; Lim, S.K. Prevalence and molecular characterization of CTX-M $\beta$-lactamase-producing Escherichia coli isolated from healthy swine and cattle. Foodborne Pathog. Dis. 2013, 10, 13-20. [CrossRef]

31. Tong, P.; Sun, Y.; Ji, X.; Du, X.; Guo, X.; Liu, J.; Zhu, L.; Zhou, B.; Zhou, W.; Liu, G.; et al. Characterization of antimicrobial resistance and extended-spectrum $\beta$-lactamase genes in Escherichia coli isolated from chickens. Foodborne Pathog. Dis. 2015, 12, 345-352. [CrossRef] [PubMed] 
32. Randall, L.P.; Lemma, F.; Rogers, J.P.; Cheney, T.E.A.; Powell, L.F.; Teale, C.J. Prevalence of extended-spectrum- $\beta$-lactamaseproducing Escherichia coli from pigs at slaughter in the UK in 2013. J. Antimicrob. Chemother. 2014, 69, 2947-2950. [CrossRef]

33. Valentin, L.; Sharp, H.; Hille, K.; Seibt, U.; Fischer, J.; Pfeifer, Y.; Michael, G.B.; Nickel, S.; Schmiedel, J.; Falgenhauer, L.; et al. Subgrouping of ESBL-producing Escherichia coli from animal and human sources: An approach to quantify the distribution of ESBL types between different reservoirs. Inter. J. Med. Microbiol. 2014, 304, 805-816. [CrossRef]

34. Zheng, H.; Zeng, Z.; Chen, S.; Liu, Y.; Yao, Q.; Deng, Y.; Chen, X.; Lv, L.; Zhuo, C.; Chen, Z.; et al. Prevalence and characterisation of CTX-M $\beta$-lactamases amongst Escherichia coli isolates from healthy food animals in China. Int. J. Antimicrob. Agents. 2012, 39, 305-310. [CrossRef] [PubMed]

35. DLD. A List of Drugs that Must not be Mixed in Animal Feed for Prophylactic Purposes. Notification of the Department of Livestock Development. The Ministry of Agriculture and Cooperatives, 2018. Available online: http://legal.dld.go.th (accessed on 20 May 2021).

36. DLD. Characteristics and Conditions of Animal feed Containing Drugs Prohibited from Producing, Importing, Selling and using. Notification of the Department of Livestock Development. The Ministry of Agriculture and Cooperatives, 2019. Available online: https:/ /legal.dld.go.th/web2012/news/P15/13136182190762.PDF (accessed on 20 May 2021).

37. Poolperm, P.; Tangkoskul, T.; Seenama, C.; Maknakhon, N.; Thamlikitkul, V. Association between the use of colistin for short-term treatment of Gram-negative bacterial infections and the emergence of colistin-resistant Enterobacteriaceae in swine from selected swine farms in Thailand. PLoS ONE 2020, 15, e0238939. [CrossRef]

38. Zhang, J.; Chen, L.; Wang, J.; Yassin, A.K.; Butaye, P.; Kelly, P.; Gong, J.; Guo, W.; Li, J.; Li, M.; et al. Molecular detection of colistin resistance genes ( $m c r-1, m c r-2$ and $m c r-3)$ in nasal/oropharyngeal and anal/cloacal swabs from pigs and poultry. Sci. Rep. 2018, 8, 1-9. [CrossRef] [PubMed]

39. Xavier, B.B.; Lammens, C.; Ruhal, R.; Kumar-Singh, S.; Butaye, P.; Goossens, H.; Malhotra-Kumar, S. Identification of a novel plasmid-mediated colistin-resistance gene, mcr-2, in Escherichia coli, Belgium, June 2016. Eurosurveillance 2016, 21, 30280. [CrossRef]

40. Falgenhauer, L.; Waezsada, S.E.; Yao, Y.; Imirzalioglu, C.; Käsbohrer, A.; Roesler, U.; Michael, G.B.; Schwarz, S.; Werner, G.; Kreienbrock, L.; et al. Colistin resistance gene $m c r-1$ in extended-spectrum $\beta$-lactamase-producing and carbapenemase-producing Gram-negative bacteria in Germany. Lancet Infect. Dis. 2016, 16, 282-283. [CrossRef]

41. Yao, X.; Doi, Y.; Zeng, L.; Luchao, L.V.; Liu, J.H. Carbapenem-resistant and colistin-resistant Escherichia coli co-producing NDM-9 and MCR-1. Lancet Infect. Dis. 2016, 16, 288-289. [CrossRef]

42. International Organization for Standardization (ISO). Microbiology of Food and Animal Feeding Stuffs-Horizontal Method for the Detection of Salmonella spp.; ISO 6579:2002; ISO: Rome, Italy, 2002.

43. Grimont, P.A.D.; Weill, F.X. Antigenic Formulae of the Salmonella Serovars, 9th ed.; World Health Organization Collaborating Center for Reference and Research on Salmonella; Institut Pasteur: Paris, France, 2007; pp. 1-166.

44. Quinn, P.J. Clinical Veterinary Microbiology; Wolfe: London, UK, 1994; p. 648.

45. Carter, G.R.; Cole, J.R., Jr. Diagnostic Procedure in Veterinary Bacteriology and Mycology; Academic Press: Cambridge, MA, USA, 2012; p. 620.

46. CLSI. Performance Standards for Antimicrobial Susceptibility Testing: Twenty-third Informational Supplement M100-S25; Clinical Laboratory Standards Institute (CLSI): Wayne, PA, USA, 2015.

47. EUCAST. European Committee on Antimicrobial Susceptibility Testing, Breakpoint Tables for Interpretation of MICs and Zone Diameters. Version 10.0. In European Committee on Antimicrobial Susceptibility Testing; 2020; Available online: http: / / www.eucast.org/clinical_breakpoints / (accessed on 25 May 2021).

48. Levesque, C.; Piche, L.; Larose, C.; Roy, P.H. PCR mapping of integrons reveals several novel combinations of resistance genes. J. Antimicrob. Chemother. 1995, 39, 185-191. [CrossRef] [PubMed]

49. Yin, W.; Li, H.; Shen, Y.; Liu, Z.; Wang, S.; Shen, Z.; Zhang, R.; Walsh, T.R.; Shen, J.; Wang, Y. Novel plasmid-mediated colistin resistance gene mcr-3 in Escherichia coli. MBio 2017, 8, e00543. [CrossRef]

50. Hasman, H.; Mevius, D.; Veldman, K.; Olesen, I.; Aarestrup, F.M. $\beta$-Lactamases among extended-spectrum $\beta$-lactamase (ESBL)resistant Salmonella from poultry, poultry products and human patients in The Netherlands. J. Antimicrob. Chemother. 2005, 56, 115-121. [CrossRef] [PubMed]

51. Batchelor, M.; Hopkins, K.; Threlfall, E.J.; Clifton-Hadley, F.A.; Stallwood, A.D.; Davies, R.H.; Liebana, E. bla ${ }_{\text {CTX-M genes in }}$ clinical Salmonella isolates recovered from humans in England and Wales from 1992 to 2003. Antimicrob. Agents Chemother. 2005, 49, 1319-1322. [CrossRef]

52. Dallenne, C.; Da Costa, A.; Decré, D.; Favier, C.; Arlet, G. Development of a set of multiplex PCR assays for the detection of genes encoding important beta-lactamases in Enterobacteriaceae. J. Antimicrob. Chemother. 2010, 65, 490-495. [CrossRef] [PubMed]

53. Sabaté, M.; Tarragó, R.; Navarro, F.; Miró, E.; Vergés, C.; Barbé, J.; Prats, G. Cloning and Sequence of the Gene Encoding a Novel Cefotaxime-Hydrolyzing $\beta$-Lactamase (CTX-M-9) from Escherichia coli in Spain. Antimicrob. Agents Chemother. 2000, 44, 1970-1973. [CrossRef]

54. Muzaheed, Y.D.; Adams-Haduch, J.M.; Endimiani, A.; Sidjabat, H.E.; Gaddad, S.M.; Paterson, D.L. High prevalence of CTX-M-15producing Klebsiella pneumoniae among inpatients and outpatients with urinary tract infection in Southern India. J. Antimicrob. Chemother. 2008, 61, 1393-1394. [CrossRef] [PubMed]

55. Woodall, C.A. DNA transfer by bacterial conjugation. In E. coli Plasmid Vectors; Nicola, C., Andrew, P., Eds.; Humana Press: Totowa, NJ, USA, 2003; pp. 61-65. 